\title{
Recycling of exposed photographic X-ray films and recovery of silver using Bromelain
}

\author{
K. V. Radha \& C. Arun \\ Department of Chemical Engineering, A. C. College of Technology, \\ Anna University, Chennai, India
}

\begin{abstract}
In the present work an environmentally friendly recycling system to peel away the base coat from the X-ray film by using an enzyme was developed. Bromelain, a proteolytic enzyme extracted from the waste apex of pineapple was used for stripping the silver layer on the exposed film by hydrolysis of gelatin. The collected film can be reused for the manufacturing of X-ray film or other materials like fabrics, packaging films, recording tapes, and soft-drink bottles. The silver recovery conditions were optimized and the slurry obtained from the treatment of X-ray with Bromelain was analyzed using a scanning electron microscope. The slurry was smelted in the presence of flux $\left(\mathrm{Na}_{2} \mathrm{CO}_{3}\right)$ in a furnace to recover $99.9 \%$ pure silver. Thus it helps in the recycling of X-ray film and recovery of silver without any harm to the environment.
\end{abstract}

Keywords: waste management, X-ray films, waste pineapple apex, Bromelain, recovery of silver, metal ion concentration, gelatin, smelting, EDAX.

\section{Introduction}

Silver is a rare, precious, naturally occurring metal, often found deposited as a mineral ore in association with other elements. Fifty percent of silver produced is used in photographic and imaging materials. Silver is unique in its ability to react with light to produce images in applications such as photography and radiography (X-rays). Major emissions of silver are from the manufacture and disposal of certain photographic and X-ray films.

X-rays films used in medical applications are made of a plastic sheet (polyester film) coated with a thin coating of gelatin (protein) impregnated with silver grain. X-ray films are normally discarded by incineration and chemical 
processing. However, the standard silver loss in an incineration process is about $25 \%-30 \%$ and the smoke produced is very toxic and illegal. The chemical processes are very difficult, expensive, inefficient and risky.

Nowadays various studies have been carried out using proteases which play a crucial role in the recycling of exposed X-ray films (Akihiko et al. [16]). Protease, referred to as proteolytic enzymes hydrolyze and digest, depolymerise or degrade or decompose protein. Bromelain is one of the proteolytic enzymes present in several varieties of pineapple fruit, the leaves, apex and stems. Bromelain breaks down the gelatin protein that serves as the support medium for the emulsion when it reacts with X-ray films. If the gelatin is destroyed the black silver grains will slough off, leaving a clear plastic sheet of the $\mathrm{x}$-ray film. The obtained slurry was dried and smelted in the presence of flux in a furnace to obtain pure silver.

The objective of the present study was the extraction and purification (Waliszewski et al. [12]) of Bromelain enzymes from the waste apex of pineapple and to study the effect of optimal environmental parameters (Khan et al. [11]). The kinetic parameters are to be estimated using gelatin as substrate. The X-ray films are treated by using Bromelain extract. It helps in the recycling of polymeric material in X-ray film and also recovers silver without any harm to the environment (Nakiboglu et al. [17]).

\section{Experiments}

\subsection{Extraction of Bromelain}

Waste pineapple apex collected from a market in Chennai, India, was used for the extraction of Bromelain, a proteolytic enzyme. The pineapple apex was cut into pieces and blended using a juice extractor. The blended tissue was homogenized using a homogenization buffer (Phosphate buffer) and this is used as crude extract. The crude extract was passed through a Buckner funnel and it was centrifuged at $7000 \mathrm{rpm}$ for 15 minutes and the supernatant was used as the crude homogenate.

\subsection{Estimation of total protein concentration}

Lowry protein assay which is used for the quantitative determination of protein concentration is described by Lowry et al [14]. In this assay tyrosine in protein reacts with Folin's ciocalteau reagent and $\mathrm{CuSO}_{4}$ solution to produce a blue colour with an absorption maximum of around $620 \mathrm{~nm}$. The concentration of protein was estimated by referring to a standard curve obtained at the same time using known concentration of bovine serum albumin.

\subsection{Proteolytic activity measurement using spectrophotometer}

Enzyme activity was defined as GDU/g of pineapple apex. Gelatin Digestion Unit (GDU) is the amount of enzyme which produces $1 \mu \mathrm{g}$ of tyrosine per minute in $1 \%$ solution of gelatin. Gelatin $(25 \mathrm{ml})$ was treated with enzyme 
solution ( $3 \mathrm{ml}$ ) in $1 \mathrm{M}$ sodium phosphate buffer for $15 \mathrm{~min}$ and the reaction was stopped by the addition of $5 \%$ trichloroacetic acid (TCA) $(25 \mathrm{ml})$. The precipitated material from each reaction mixture was removed by centrifugation and the supernatant was assayed by Lowry's method. An appropriate blank solution was also prepared and absorbance values at $620 \mathrm{~nm}$ were measured with reference to the blank using spectrophotometer (SL177, scanning minispec, ELICO LTD, type 212, India). The absorbance values obtained could be correlated with enzyme activity.

\subsection{Effect of temperature on enzyme activity}

The effect of temperature of the crude enzyme on the reaction was determined by incubating the reaction mixture containing Bromelain solution and $2 \%$ gelatin solution. Reaction was allowed for 15 minutes at different temperatures from $30^{\circ} \mathrm{C}$ to $60^{\circ} \mathrm{C}$ at intervals of 5 and the reaction stopped with $3 \mathrm{ml}$ of $5 \%$ trichloroacetic acid. An appropriate blank solution was also prepared and absorbance values at $620 \mathrm{~nm}$ were measured with reference to the blank. The absorbance values obtained could be correlated with enzyme activity.

\subsection{Effect of PH on enzyme activity}

The effect of $\mathrm{pH}$ of the crude enzyme on the reaction was determined by incubating the reaction mixture containing Bromelain solution and $1 \%$ gelatin solution. Reaction was allowed for 15 minutes at $55^{\circ} \mathrm{C}$ with different $\mathrm{pH}$ from 4.5 to 8 at intervals of 0.5 and the reaction stopped with $3 \mathrm{ml}$ of $5 \%$ trichloroacetic acid. An appropriate blank solution was also prepared and absorbance values at $620 \mathrm{~nm}$ were measured with reference to the blank. The absorbance values obtained could be correlated with enzyme activity.

\subsection{Effect of substrate concentration on enzyme activity}

$100 \mathrm{ml}$ of enzyme solution was taken in conical flask and to it different grams (550 at equal intervals) of waste X-ray film (gelatine) was added at a temperature of $55^{\circ} \mathrm{C}$ and $\mathrm{pH} 6$ for 1 hour to strip the silver materials from the X-ray films. After 1 hour $\mathrm{x}$ ray films are separated from the solution and the solution was centrifuged. The precipitate was dried and weighed and this could be correlated with enzyme activity.

\subsection{Effect of initial enzyme concentration on enzyme activity}

20 grams of waste X-ray film (gelatine) was taken in conical flask and to it 5$35 \mathrm{ml}$ (at equal interval) enzyme solution was added and the reaction was taken at $55^{\circ} \mathrm{C}$ with $\mathrm{pH} 6$ for 1 hour to strip out the silver materials from the X-ray films. After 1 hour X-ray films are separated from the solution and solution was centrifuged. The precipitate was dried and weighed and the values could be correlated with enzyme activity. 


\subsection{Effect of metal ions on enzyme activity}

The effect of metal ions (ferrous, copper, silver, lead, cobalt, chromium) was determined by reacting $1 \%$ gelatin solution in the presence of 1 gram of different metal ions with the enzyme solution. The reaction is carried out for 15 minutes at a temperature of $55^{\circ} \mathrm{C}$ and the reaction stopped with the addition of $3 \mathrm{ml}$ of $5 \%$ trichloroacetic acid. An appropriate blank solution was prepared and absorbance values at $620 \mathrm{~nm}$ were measured with reference to the blank. The absorbance values obtained could be correlated with enzyme activity.

\subsection{Effect of time on silver recovery}

20 grams of waste X-ray film (gelatine) was taken in a conical flask and to it $30 \mathrm{ml}$ of enzyme solution was added and the reaction was carried out at $55^{\circ} \mathrm{C}$ and $\mathrm{pH} 6$ for different time intervals(5-40) to strip off the silver materials from the X-ray films. X-ray films are separated from the solution and solution was centrifuged. The percentage of silver present in the precipitate was analyzed.

\subsection{Treatment of X-ray film using Bromelain}

X-ray film, coated on both sides with gelatine is first washed with distilled water and wiped with cotton impregnated with ethanol and cut into pieces. Fig 6 clearly shows the flow chart that explains the treatment process. Before treatment it was heated in an oven at $50^{\circ} \mathrm{C}$ for 30 minutes and each film was immersed in Bromelain enzyme at $55^{\circ} \mathrm{C}$ and at $\mathrm{pH} 6$ for 1 hour. Essentially, all the silver had been removed from the film and the treated X-ray films are separated from the solution and solution was centrifuged. The precipitate was dried.

\subsection{Silver purification}

The precipitate obtained was dried and mixed with sodium carbonate placed in a crucible and smelted for $30 \mathrm{~min}$ at $750^{\circ} \mathrm{C}$. The smelted silver was quenched to form silver grain. This will give pure silver grains.

\section{Results and discussion}

\subsection{Estimation of total protein concentration}

The total protein was estimated by referring to a standard curve (Figure 1) obtained using a known concentration of bovine serum albumin. The protein content of unknown solutions (enzyme) was found by comparing the color produced by the unknowns with the standard curve. Total protein was found to be $0.959 \mathrm{mg} / \mathrm{ml}$ and after purification of enzymes whose total protein content is $0.872 \mathrm{mg} / \mathrm{ml}$. 


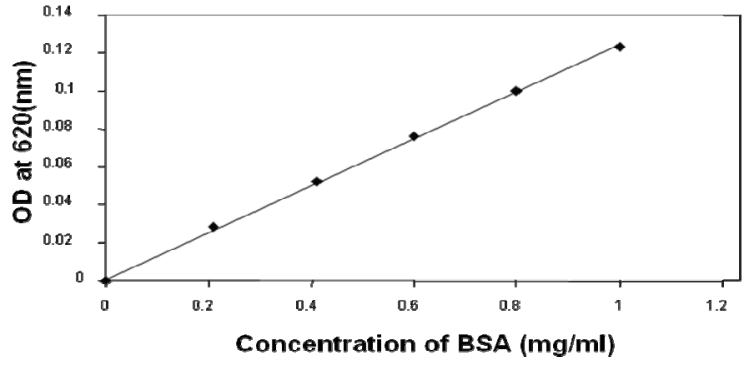

Figure 1: $\quad$ Standard graph for estimation of protein concentration.

\subsection{Effect of temperature on enzyme activity}

The effect of temperature on enzyme activity with varies temperature ranges were studied. Increase in temperature will increase the reaction rate until the enzyme becomes denatured and the maximum operating temperature was determined as $55^{\circ} \mathrm{C}$ using gelatin as substrate (Figure 2). Similar work has been conducted by Koh et al. [9] showing that the optimum temperature was found to be $60^{\circ} \mathrm{C}$ for fruit extract from pineapple using azocasein and casein as substrate respectively.

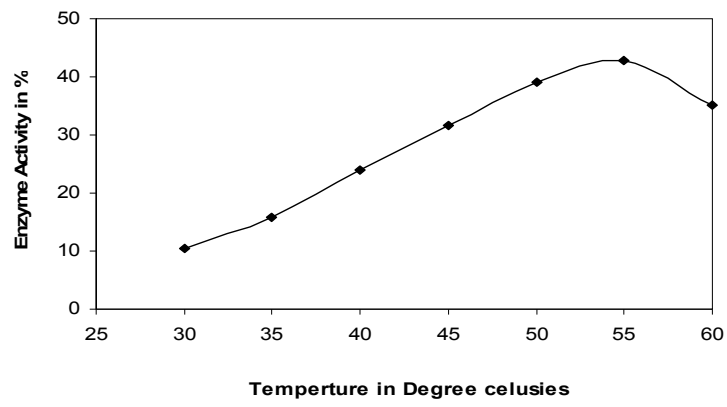

Figure 2: $\quad$ Effect of temperature on enzyme activity.

\subsection{Effect of ph on enzyme activity}

Protease enzymes generally can be categorized into two groups with respect to their optimal $\mathrm{pH}$ acidic or alkaline. The effect $\mathrm{pH}$ on the activity of the enzyme was investigated using gelatin as substrate. The maximum operating $\mathrm{pH}$ for Bromelain from pineapple apex was found to be $\mathrm{pH} 6.5$ (Figure 3). From the result, Bromelain extracted from pineapple apex was confirmed as acidic protease. Similar result was reported by Waliszewski et al [12] showed fruit Bromelain has optimum $\mathrm{pH}$ 6.5. 


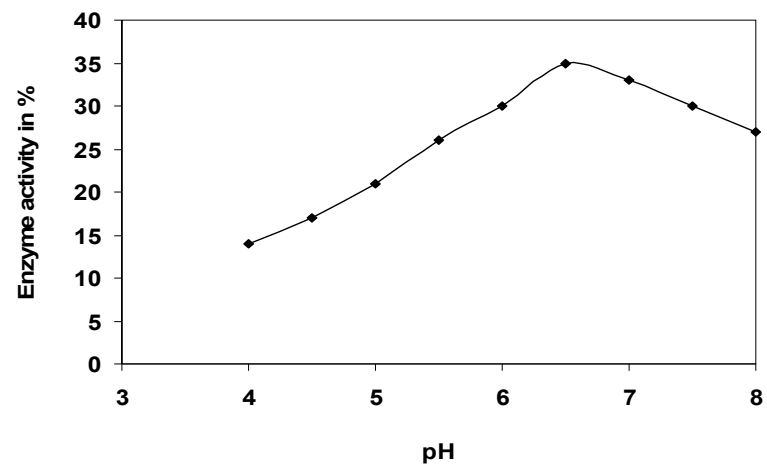

Figure 3: $\quad$ Effect of $\mathrm{pH}$ on enzyme activity.

\subsection{Effect of substrate concentration and initial enzyme concentration on enzyme activity}

Enzyme activity was higher for a substrate concentration (Figure 4) was higher $(24.6 \%)$ at the value of $35 \mathrm{~g}$ of X-ray film $/ 50 \mathrm{ml}$ of enzyme solution. The effect of initial enzyme concentration gave a linear increment in enzyme activity and it was higher $(18.2 \%)$ at a value of $20 \mathrm{~g}$ of X-ray film per $30 \mathrm{ml}$ of enzyme solution.

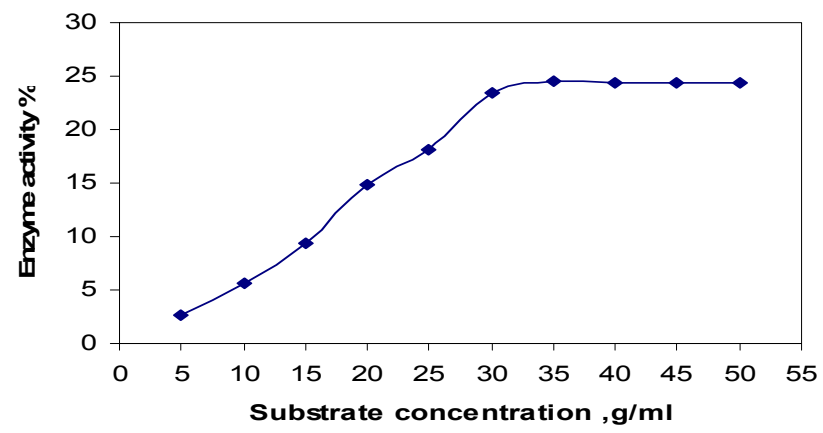

Figure 4: $\quad$ Effect of substrate concentration on enzyme activity.

\subsection{Effect of time on silver recovery}

The effect of time on silver recovery (Figure 5) shows that at $35 \mathrm{~min}$ the recovery percentage is higher, i.e. $99.3 \%$. From the results obtained it is clearly evident that time conception is much less for the treatment of X-ray film using Bromelain when compared with other chemical treatment methods. 


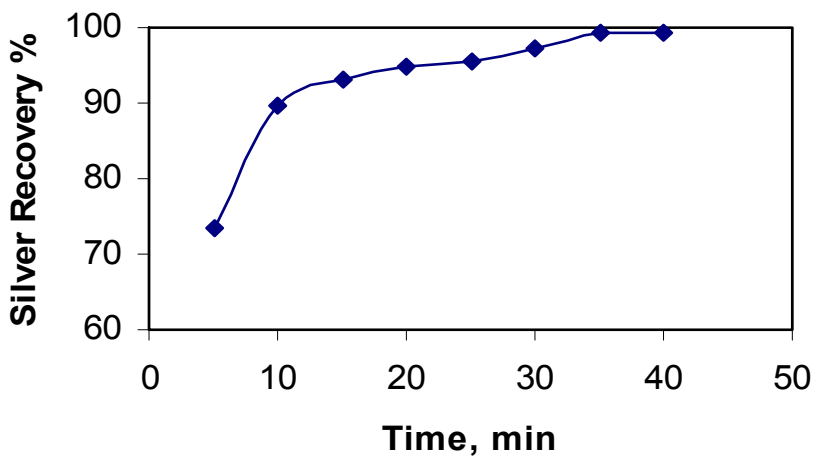

Figure 5: $\quad$ Effect of time on silver recovery.

\subsection{Effect of metal ions on enzyme activity}

The effect of metal ion (ferrous, copper, silver, lead, cobalt, chromium) on enzyme activity (Figure 6) shows that cobalt and copper seems to affect the enzyme activity to a large extent. It was found that the effect of silver on enzyme activity is negligible so this shows that silver present in X-ray film will not affect the enzyme and substrate reaction.

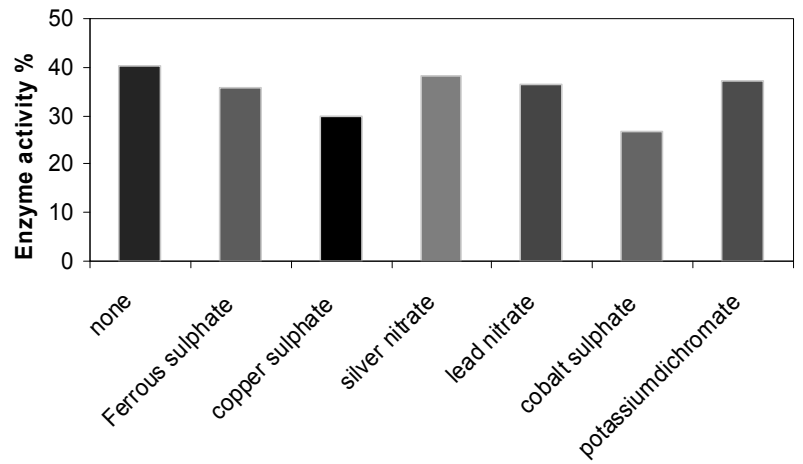

Figure 6: $\quad$ Effects of metal ions on enzyme activity.

\subsection{Treatment of X-ray film using Bromelain}

$1 \mathrm{~g}$ of waste X-ray film was treated using $100 \mathrm{ml}$ of Bromelain crude extract to strip out the silver materials from the $\mathrm{X}$-ray films at $55^{\circ} \mathrm{C}$ and $\mathrm{pH} 6$ for $35 \mathrm{~min}$ and the cleared polymeric material can be reused. Figure 7 shows that the X-ray films before and after treatment. Similarly, Nakiboglu et al. [17] has reported that the protease from Bacillus subtilis decomposes the gelatin layer and clears the film by stripping out the silver grains on them at $50^{\circ} \mathrm{C}$. But the purification step is difficult and at the same time maintaining the microbe at its optimum condition is very important. But this process is comparatively easier, the process 


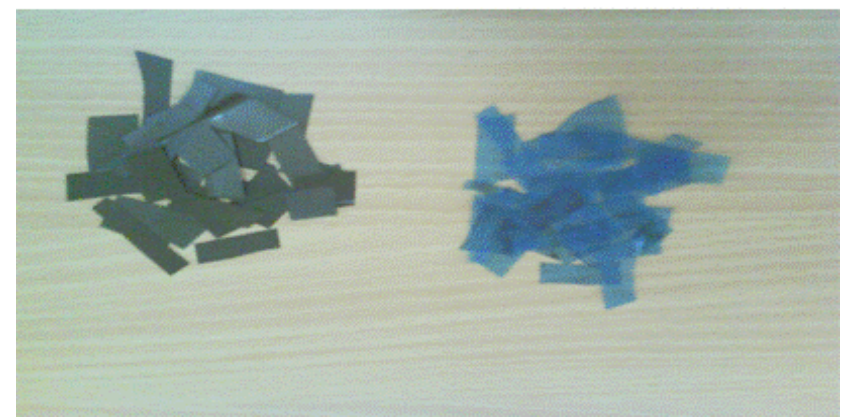

Figure 7: $\quad$ X-ray film before and after treatment.

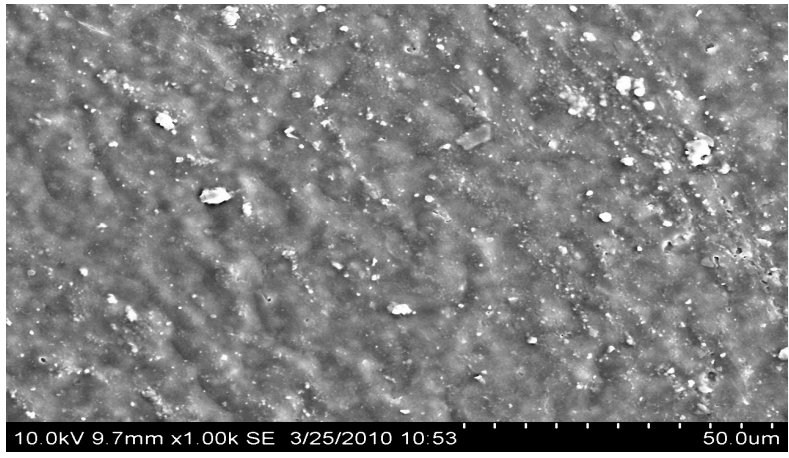

Figure 8: $\quad$ SEM Image of X-ray film before treatment with Bromelain.

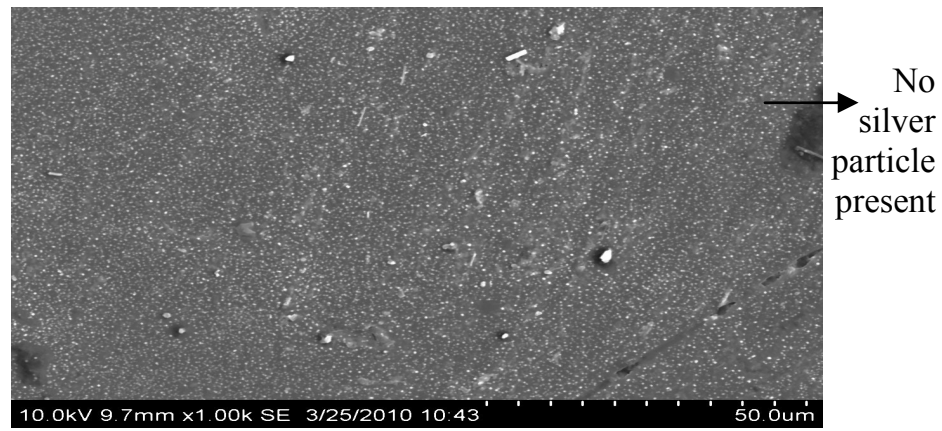

Figure 9: $\quad$ SEM Image of X-ray film after treatment with Bromelain. The silver particle is completely stripped out from the polymeric material. 
is cheaper because the enzyme was extracted from waste pine apple apex and the process is pollution free. SEM studies performed before (Figure 8) and after treatment (Figure 9) shows that all sliver grains on the X-ray film was completely stripped out from polymeric material.

\section{Conclusions}

The Bromelain enzyme was extracted by using the juice extracted from pineapple apex. Concentration of total protein in crude homogenate was estimated at $0.959 \mathrm{mg} / \mathrm{ml}$ and after purification the concentration of total protein was found to be $0.872 \mathrm{mg} / \mathrm{ml}$. Maximum operating ph and temperature for Bromelain was found to be 6.5 and $55^{\circ} \mathrm{C}$ respectively. Effect of time on silver recovery shows that at $35 \mathrm{~min}$ essentially all sliver grains on X-ray film was completely stripped out from the polymeric material. It is confirmed by analyzing the X-ray film before and after treatment using SEM. The cleared X-ray film was collected and dried. The collected film can be reused for manufacturing of X-ray film and also used for production of fabrics, packaging films, recording tapes, and soft-drink bottles. All the above results show that this process is cheaper, pollution free and efficient. By this process $98 \%$ of silver can be recovered from X-ray film and the silver can be reused for silver solder, jewels, silver plating of utensils, electrical components and film manufacture. The purity of silver obtained was found to be $99.9 \%$. Thus this process is an eco friendly process.

\section{References}

[1] Adani K.G, Barley R.W \& Pascoe R.D., Silver recovery from synthetic photographic and medical X-ray process effluents using activated carbon. Minerals Engineering 18, pp.1269-1276, 2005.

[2] Barun K Bhattacharyya, Bromelain: An Overview, Natural Product Radiance 7(4) 359-363, pp.2008.

[3] Datye K.V, Raje H.M \& Sharma N.D., Poly (Ethylene Terephthalate) Waste and its Utilization: A Review, Resources and Conservation 11, pp.117-141, 1984.

[4] Dusenberry, Silver recovery process, United States Patent, 3960550, 1976.

[5] Frattini Fileti A.M, Fischer G.A, \&Tambourgi E.B., Optimizing Bromelain Extraction by Reversed Micelles from Pineapple Fruit, Brazilian Journal of Chemical Engineering, 17,pp.29-38,2005 .

[6] Geyken E, \& Dawidowitsch P., Apparatus for processing photographic film and treating contaminated processing liquids. US Patent, 4081816, 1978.

[7] Glider, W. V., Hargrove, M. S., Using Bromelain in pineapple juice to investigate enzyme function, tested studies for laboratory teaching pp.275295, 2002.

[8] Grout, M. Kenneth, Method and apparatus for recovering silver and plastic from used film. United States Patent 4392889, 1983. 
[9] Joonseok Koh, Sang-Mo Kang, Soo-Jin Kim, Min-Kyung Cha, Yoon-Jung Kwon, Effect of pineapple protease on the characteristics of protein fibers, 7, pp.180-185, 2006 .

[10] Kalpana Devi M, Rasheedha Banu M, Gnanaprabhal G.R, Pradeep B.V.\& Palaniswamy M., Purification, characterization of alkaline protease enzyme from native isolate Aspergillus niger and its compatibility with commercial detergents, J. Sci. Technol 7, pp.1-5, 2008.

[11] Khan R .H, Rasheedi S \& Haq S K, Effect of $\mathrm{pH}$, temperature and alcohols on the stability of glycosylated and deglycosylated stem bromelain, J. Biosci, 28, pp. 709-714, 2003.

[12] Krzysztof Waliszewski N, Ofelia Márquez \& Violeta Pardio T., Quantification and characterisation of polyphenol oxidase from vanilla bean, Food Chemistry 117, pp.196-203, 2009.

[13] Line weaver H \& Burk D., The Determination of Enzyme Dissociation Constants. Journal of the American Chemical Society, 56, pp. 658-666, 1934.

[14] Lowry O. H, Rosebrough N. J, Farr A. L \& Randal R. J, J. Biol. Chem 193 265-275,1951.

[15] Marinkovic J, Korac M, Kamberovic Z \& Matic I., Recycling of Silver from Exposed X Ray Films, Aeta Metallurgica slovaca, pp. 262-268, 2006.

[16] Masui Akihiko, Masahiro Yasuda, Nobuaki Fujiwara, Haruo Ishikawa., Enzymatic Hydrolysis of Gelatin Layers on Used Lith Film Using Thermostable Alkaline Protease for Recovery of Silver and PET Film. Biotechnol. Progress, 20 (4) pp. 1267-1269, 2004.

[17] Nuri Nakiboglu, Duygu Toscali, Ihsan Yasa., Silver Recovery from Waste Photographic Films by an Enzymatic Method, Turk J Chem pp. 349-353, 2001.

[18] Nuri Nakiboglu, Duygu Toscali Ihsan Yasa, A Novel Silver Recovery Method From Waste Photographic Films With Naoh Stripping, Turk J Chem pp. $127-133,2003$.

[19] Pickles Christopher A, Toguri James Truong M, Hieu, Clark, Janet G, Recovery of silver values from chlorides including silver chloride. United States Patent 5085692, 1992.

[20] Puchalski M, Dąbrowski P, Olejniczak W, P. Krukowski, P. Kowalczyk, K. Polański, The study of silver nanoparticles by scanning electron microscopy, energy dispersive $\mathrm{x}$-ray analysis and scanning tunnelling microscopy, Materials Science-Poland 25 (2), pp.473-478 (2007).

[21] Rabelo A. P. B, E. Tambourgi B, Pessoa Jr. A, Bromelain portioning in two-phase aqueous systems containing PEO-PPO-PEO blocks copolymers, Journal of Chromatography, 807, pp. 61-68,2004.

[22] Waliszewski W \& Corzo C, Crude fruit-Bromelain affinity to different protein substrates. IFT Annual Meeting, section 49E-30, 2004.

[23] Han Z.X, Wei J.Y, Zhao M \& Hu J.F, A method to recover silver from waste X-ray films with spent fixing bath. Hydrometallurgy 92, pp.148-151, 2008. 